\title{
HUBUNGAN STIFIN DENGAN PROFESIONALITAS GURU
}

\section{STIFIN RELATIONSHIP WITH PROFESIONALISM TEACHER}

\author{
A Sundari'1a, A Mahrudin'1, dan A Kholik ${ }^{1}$ \\ 1 Program Studi Manajemen Pendidikan Islam, Fakultas Keguruan dan Ilmu Pendidikan, \\ Universitas Djuanda Bogor, Jl. Tol Ciawi No. 1 Kotak Pos 35 Ciawi Bogor 16720 \\ a Korespondensi: Agnia Sundari, Email: agniasundari9@gmail.com
}

(Diterima: 27-01-2019; Ditelaah: 29-01-2019; Disetujui: 10-03-2019)

\begin{abstract}
Based on the result of school observation statment SMK Informatika Pesat Bogor apply STIFIn test especially for teachers, that it's because there is a policy of the foundation for teachers in carrying out the STIFIn test. Where at the time there was a deerease in teacher performance, so the foundation decided to carry out the STIFIn test conducted on each teacher there is change in the performance of the teacher. This Study aims to find out whether there is a reliationship betweenSTIFIn test result and profesionalism of teachers at SMK Informatika Pesat Bogor. This research was conducted at SMK Informatika Pesat Bogor, especially for teachers. Subjects in this study are all th teachers whom are as many as 23 of them. Data was collected by using observation technique, interviews, an questionaires. And the method used in this research is quantitative method with correlation technique.The final result of the research is the theoritical chi-square value significance level $5 \%=12,529$. Calculation result in chi-square table obtained value $X^{2}$ hitung $=0.01$ and d.b $=6$ obtained value $\mathrm{X}_{\text {tabel }}=12,592$, so out of those result because of the value $\mathrm{X}^{2}$ hitung $<\mathrm{X}^{2}$ tabel $=0,01<12,592$, then $\mathrm{H}_{0}$ is accepted and $\mathrm{H}_{1}$ isrejected.The conclusion shows that there is a relationship between STIFIn test result and profesionalism of teachers at SMK Informatika Pesat Bogor.
\end{abstract}

Keywords: profesionalism, STIFIn, teacher.

\begin{abstract}
ABSTRAK
Berdasarkan hasil observasi sekolah statmen SMK Informatika Pesat menerapkan tes STIFIn terhadap semua gurunya, yaitu karena ada kebijakan dari yayasan untuk para guru dalam melaksanakan tes STIFIn. Dimana pada saat itu ada penurunan dalam hal kineja guru yang kurang, sehingga pihak yayasan memutuskan untuk melaksanakan tes STIFIn kepada seluruh gurunya. Dengan demikian setelah dilaksanakan tes STIFIn terhadap masing-masing guru terdapat perubahan dalam kinerja guru tersebut. Penelitian ini bertujuan utnuk mengetahui apa ada hubungan antara STIFIn dengan profesionlitas guru di SMK Informatika Pesat Bogor. Penelitian ini dilaksanakan di SMK Informatika Pesat Bogor, kuhusunya untuk guru. Subjek dlaam penelitain ini adalah jumlah guru seluruhnya yaitu sebanyak 23 orang guru. Perolehan data yaitu dnegan menggunakan teknik observasi, wawacara dan kuesioner. Serta untuk peneliti menggunakan metode penelitian pada penelitian ini yaitu metode kuantitatif dengan teknik korelasional. Hasil akhir penelitian ini yaitu harga chi-kuadrat teoritik untuk taraf signifikansi $5 \%=12$, 592. Hasil perhitungan dalam tabel chi-kuadrat yang diperoleh nilai $\mathrm{X}^{2}$ hitung $=0,01$ dan d.b $=6$ didapat nilai $\mathrm{X}^{2}$ tabel $=12,592$, jadi dari hasil tersebut karena nilai $\mathrm{X}^{2}$ hitung $<\mathrm{X}^{2}$ tabel $=0,01<12,592$, maka $\mathrm{H}_{0}$ diterima dan $\mathrm{H}_{1}$ ditolak. Kesimpulannya yaitu bahwa terdapat hubungan antara STIFIn dengan profesionalitas guru di SMK Informatika Pesat Bogor.
\end{abstract}

Kata kunci: guru, profesionalitas, STIFIn. 
Sundari, A., Mahrudin, A., \& Kholik, A. (2019). Hubungan STIFIn dengan Profesionalitas Guru. Tadbir Muwahhid, 3(1), 1-13.

\section{PENDAHULUAN}

Guru merupakan penentu keberhasilan pendidikan melalui kinerjanya pada tingkat institusional dan instruksional. Peran strategis tersebut sejalan dengan UndangUndang No 14 tahun 2005 tentang Guru dan Dosen, yang menempatkan guru sebagai tenaga profesional sekaligus sebagai agen pembelajaran. Sebagai tenaga profesional, pekerjaan guru hanya dapat dilakukan oleh seseorang yang mempunyai kualifikasi akademik, kompetensi, dan sertifikat pendidik sesuai dengan persyaratan untuk setiap jenis dan jenjang pendidikan tertentu. Kedudukan guru sebagi tenaga profesional mempunyai visi terwujudnya penyelenggaraan sesuai dengan prinsip profesionalisme untuk memenuhi hak yang sama bagi setiap warga negara dalam memperoleh pendidikan yang bermutu (Priansa, 2015).

Harus disadari bahwa guru dan dunia pendidikan merupakan satu kesatuan yang tidak terpisahkan. Pendidikan akan hidup ketika guru mampu menciptakan suasana belajar (Learning Situation) yang humanis dan demokratis dengan orientasi visi yang jelas. Guru pun akan memberikan performance yang baik dan akan menjalankan proses instruksional yang optimal ketika eksistensinya betul-betul dihargai dalam institusi pendidikan. Sebab, guru merupakan salah satu pilar utama keberhasilan dunia pendidikan yang akan melahirkan output yang berkualitas, bahkan guru pula yang dapat menentukan maju dan hancurnya sebuah negara (Bisri, 2015 ).
Sejarah perjalanan manusia mencatat bahwa pekerjaan manusia yang paling dihormati adalah guru. Hampir semua orang besar adalah guru. Semua Rasul adalah guru. Muhammad saw sendiri seorang guru. Hadist riwayat Muslim. Ahmad Ibnu Majah dan Al-Darimi jelas sekali menunjukkan profesi Rasulullah ini innama buitsu mu'alim ("sesungguhnya aku diutus menjadi guru"). Empat Khulafaur Rasyidin semuanya adalah guru. 'Aisyah, Anas, Abu Hurairah, Ibn Abbas, Ibn Umar, Ibn Mas'ud, Mu'az, Bilal, Salman, dan masih banyak lagi sahabat yang lain, semuanya adalah guru (Aqib, 2009).

Betapa mulianya menjadi seorang guru, selain guru harus memiliki kepribadian yang baik serta wawasan yang luas, lebih baik lagi juga jika seorang guru memahami pribadinya sendiri. Oleh karena itu manusia selain memiliki tubuh yang bersifat materi, juga mempunyai sisi nonmaterial. Sisi nonmaterial tersebut, diantaranya ingatan, pikiran, perasaan, dan kecerdasan atau kecerdasan relatif, di samping fungsi seluruh indra manusia, berpusat di otak (S.M.Masykur, 2012).

Kecerdasan yang dimiliki manusia merupakan salah satu anugerah besar dari Allah SWT menjadikannya sebagai salah satu kelebihan manusia dibandingkan dengan makhluk lainnya, dengan kecerdasannya, manusia dapat terus menerus mempertahankan dan meningkatkan kualitas hidupnya yang semakin kompleks, melalui proses berpikir dan belajar secara terus-menerus (Iskandar, 2012). Seiring perkembangan zaman yang semakin modern, banyak hal yang ditawarkan khususnya untuk menawarkan jasa dalam mengukur kecerdasan seseorang 
dengan berbagai cara, contohnya, yaitu dengan melakukan psikotes dan lain sebagainya. Sehingga mempermudah manusia untuk mengukur kemampuan dirinya sendiri. Selain itu pada zaman modern ini berkembang dalam mengukur kecerdasan dengan menggunakan tes sidik jari. Tes sidik jari itu dinamakan tes STIFIn. Konsep STIFIn adalah suatu konsep kecerdasan yang dikembangkan oleh salah satu ilmuan Indonesia dengan melalui tes sidik jari, yaitu dengan cara men-scan kesepuluh ujung jari untuk mendapatkan hasilnya. STIFIn sendiri yaitu singkatan dari lima mesin kecerdasan Sensing, Thinking, Intuiting, Feeling dan Insting.

Berdasarkan hasil observasi dari beberapa sekolah yang ada di kota Bogor. Salah satu sekolah yang menerapkan STIFIn yaitu SMK Informatika Pesat Bogor, mengapa SMK Informatika Pesat Bogor menerapkan tes STIFIn terhadap semua gurunya, yaitu karena ada kebijakan dari yayasan untuk para guru dalam melaksanakan tes STIFIn. Dimana pada saat itu ada penurunan dalam hal kinerja guru yang kurang. Sehingga pihak yayasan memutuskan untuk melaksanakan tes STIFIn kepada seluruh gururnya. Kelebihan menggunakan tes STIFIn pihak yang memberi kebijakan mengetahui beberapa kriteria dari finger print tersebut terhadap para guru dan kita bisa mengetahui kebijakan apa yang harus dilakukan sekolah. Serta adanya peningkatan yaitu pertama dari segi keterlambatan, kehadiran menjadi lebih baik, serta kinerja guru pun sekarang jauh lebih baik.

Setelah dilaksanakan tes STIFIn terhadap masing-masing guru. Terdapat perubahan dalam kinerja guru tersebut, karena guru dapat mengenali pribadi mereka masingmasing sehingga selain mempermudah pihak kepala sekolah dalam mengawasi seluruh guru namun mempermudah juga bagi setiap guru tersebut dalam mengenali dirinya sendiri serta melaksanakan tugasnya sesuai mesin kecerdasan yang dimiliki guru tersebut. Serta pihak sekolah dapat lebih lancar dalam berkomunikasi jika ada permasalahan, dan mengetahui karakter guru tersebut bagaimana, sehingga dalam menyelesaikannya lebih baik. Ada beberapa prestasi yang sudah diraih oleh beberapa guru di SMK Informatika Pesat yaitu, LKS (Lomba Kompetensi Siswa) tingkat Kota Bogor dan dua orang guru SMK Informatika Pesat yaitu guru MTK dan Olahraga/ penjaskes menjadi instruktur Nasional kegiatan guru, pembelajaran tahun 2017.

Allah telah menyediakan wadah kecerdasan tepatnya di dalam sel-sel otak. Dari sini, selama proses belajar berlangsung proses karya pikir diproduksi dan berkembang sampai tahap manusia mencapai puncak kompetensi maksimalnya. Kecerdasan seseorang berkembang seiring kualitas belajar yang dialaminya.

Di dalam Al-Qur'an surat Ar-Rum ayat 30 dijelaskan: "Maka hadapkanlah wajahmu dengan lurus kepada agama Allah, tetaplah atas fitrah Allah yang telah menciptakan manusia menurut fitrah itu. Tidak ada perubahan pada fitrah Allah. (itulah) agama yang lurus: tetapi kebanyakan manusia tidak mengetahui. (Q.S Ar-Rum :30)

Sebagaimana dijelaskan pada ayat di atas bahwa Allah SWT, telah memberikan fitrah kepada manusia untuk berpikir dan belajar sebagai makhluk Allah yang sempurna, manusia diberikan akal untuk berpikir dan terus belajar sebab manusia telah diberikan kecenderungan jiwa belajar melakukan halhal yang baik dan terpuji ( Wahab, 2016).

Dipilihnya judul penelitian "Hubungan STIFIn Dengan Profesionalitas Guru Di SMK Informatika Pesat Bogor" adalah hal yang 
unik serta menarik dalam pembahasan konsep STIFIn, karena belum banyak orang yang meneliti mengenai mesin kecerdasan STIFIn itu sendiri di Universitas Djuanda pun belum ada yang meneliti mengenai mesin kecerdasan STIFIn maka dari itu peneliti tertarik dengan judul penelitian tersebut. Peneliti memilih SMK Informatika Pesat Bogor sebagai objek penelitian ini adalah karena tidak semua sekolah menerapkan konsep STIFIn, di Bogor hanya ada beberapa sekolah yang menerapkan konsep STIFIn salah satunya adalah SMK Informatika Pesat Bogor. Sebagai indikatornya adalah seluruh guru di SMK Informatika Pesat Bogor.

\section{METODE}

\section{Jenis Penelitian}

Metode yang digunakan dalam penelitian ini adalah metode kuantitatif dengan teknik korelasional. Metode kuantitatif yaitu penelitian yang menekankan analisisnya pada data numerical atau angka yang diperoleh dengan metode statistik serta dilakukan rangka pengujian hipotesis sehingga diperoleh signifikansi hubungan antara variabel yang diteliti.

Menggunakan teknik korelasi (hubungan), yaitu merupakan suatu bentuk analisis inferensial yang digunakan untuk mengetahui derajat atau kekuatan hubungan, bentuk atau hubungan timbal balik diantara variabel-variabel penelitian (Supardi, 2013).

\section{Waktu dan Tempat Penelitian}

Waktu penelitian dilakukan pada bulan Februari 2018 - Juni 2018. Adapun tempat penelitian ini dilakukan di SMK Informatika Pesat Bogor yang beralamat di Jl. Poras No
7, Sindang Barang Loji Kota Bogor, Jawa Barat 18117.

\section{Target/Subjek Penelitian}

Populasi adalah wilayah generalisasi yang terdiri atas obyek/subyek yang mempunyai kualitas dan karakteristik tertentu yang ditetapkan oleh peneliti untuk dipelajari dan kemudian ditarik kesimpulannya (Sugiyono, 2017). Populasi yang diambil dalam penelitian ini adalah seluruh guru yang berada di SMK Informatika Pesat yang berjumlah 23 orang.

Sampel adalah sebagian atau wakil populasi yang diteliti. Dalam penelitian ini banyak hal yang harus dipertimbangkan dalam menentukan besarnya sampel. Untuk menentukan besarnya sampel, peneliti harus memahami unit analisis satuan yang menunjuk pada subjek penelitian. Unit analisis merupakan satu faktor yang dipertimbangkan oleh peneliti dalam menentukan besarnya sampel disamping pendekatan, ciri-ciri khusus yang ada pada populasi dan keterbatasannya yang ada pada peneliti. Untuk menentukan jumlah sampel, dalam penelitian ini, seluruh anggota populasi dijadikan sampel. Jumlah guru seluruhnya 23 orang. Dengan demikian dikarenakan peneliti menggunakan unit analisis sekolah khusus, maka peneliti hanya mengambil beberapa subjek penelitian saja karena subjeknya tergolong langka (Arikunto, 2013).

Teknik sampling yang digunakan oleh peneliti yaitu Non probability sampling. Non probability sampling adalah teknik pengambilan sampel yang tidak memberikan peluang/kesempatan yang sama bagi setiap unsur anggota populasi untuk dipilih menjadi sampel. Jenisnya yaitu sampel jenuh. Hal ini dilakukan bila jumlah populasi relatif kecil, kurang dari 30 orang, atau penelitian yang ingin membuat 
generalisasi dengan kesalahan yang sangat kecil.

\section{Prosedur Penelitian}

Prosedur penelitian yang dibuat oleh peneliti, diantaranya sebagai berikut:

1. Pra lapangan, langkah pertama yang ditempuh oleh peneliti dalam memulai penelitian adalah mencari sekolah yang berkaitan dengan judul penelitian, setelah itu mempersiapkan administrasi terkait perizinan kepada pihak sekolah dengan membuat surat perizinan observasi, jika sudah diterima maka peneliti melanjutkan penelitian di sekolah tersebut.

2. Eksplorasi, merupakan tahapan dalam mengumpulkan data mengenai gambaran umum SMK Informati Pesat, pada tahap ini peneliti melakukan observasi dengan mewawancarai salah satu informan guna mengetahui sejauh mana STIFIn diterapkan dan dilaksanakan pada sekolah tersebut. Sehingga peneliti mengetahui sejauh mana sekolah tersebut telah menerapkan STIFIn serta kondisi guruguru sebelum dilaksanakan tes STIFIn hingga setelah melaksanakan tes STIFIn

3. Member check, langkah ini dilakukan dengan cara peneliti menyususn kembali semua data-data yang diperoleh melalui wawancara, observasi, dan angket. Tujuannya untuk mendapatkan ketepatan, menguji konsisten responden dan mengetahui validitas data.

\section{Instrumen dan Teknik Pengumpulan Data}

Teknik pengumpulan data dapat dilakukan dengan observasi, wawancara, dan kuesioner. Teknik pertama yaitu observasi. Observasi disebut pula dengan pengamatan meliputi kegiatan pemuatan perhatian terhadap suatu objek dengan menggunakan seluruh alat indra. Dalam penelitian ini peneliti menggunakan jenis observasi tidak terstruktur, observasi tidak terstruktur adalah observasi yang tidak dipersiapkan secara sistematis tentang apa yang akan diobservasi. Hal ini dilakukan karena peneliti tidak tahu secara pasti tentang apa yang akan diamati (Arikunto, 2013).

Wawancara (interview) merupakan salah satu bentuk teknik pengumpulan data yang banyak digunakan dalam penelitian deskriptif kualitatif dan deskriptif kuantitatif. Wawancara dilakukan secara lisan dalam pertemuan tatap muka secara individual. Peneliti menggunakan jenis wawancara tidak terstruktur yaitu wawancara yang bebas dimana peneliti tidak menggunakan pedoman wawancara yang digunakan hanya berupa garis-garis besar permasalahan yang akan ditanyakan (Sugiyono, 2017). Wawancara disini ditujukan pada satu informan guru bidang kemahasiswaan yang ada di SMK Informatika Pesat Bogor.

Kuesioner merupakan suatu teknik atau cara pengumpulan data secara tidak langsung (peneliti tidak langsung bertanyatanya kepada responden). Kuesioner yang digunakan peneliti yaitu kuesioner tertutup. Peneliti menggunakan kuesioner pada variabel Y, yaitu profesionalitas guru. Responden dalam penelitian ini adalah seluruh guru yang ada di SMK Informatika Pesat Bogor.

Pada prinsipnya meneliti adalah melakukan pengukuran, maka harus ada alat ukur yang baik. Alat ukur dalam penelitian biasanya dinamakan instrumen penelitian. Adapun kisi-kisi instrumen yang digunakan hanya variabel $Y$ yaitu profesionalitas guru, kisi-kisi instrumen sesuai dengan Tabel 1. 
Tabel 1 Kisi-kisi instrumen penelitian

\begin{tabular}{|c|c|c|c|c|}
\hline Variabel & Indikator & Paramater & $\begin{array}{l}\text { Nomor } \\
\text { Item }\end{array}$ & $\begin{array}{c}\text { Jumlah Butir } \\
\text { Soal }\end{array}$ \\
\hline \multirow[t]{9}{*}{$\begin{array}{l}\text { Profesionalitas } \\
\text { Guru }\end{array}$} & $\begin{array}{l}\text { Mempunyai } \\
\text { pengetahuan } \\
\text { tentang belajar dan } \\
\text { tingkah laku } \\
\text { manusia }\end{array}$ & $\begin{array}{l}\text { Mengetahui teori } \\
\text { tentang belajar }\end{array}$ & 1,2 & 2 \\
\hline & & $\begin{array}{l}\text { Evaluasi } \\
\text { pembelajaran }\end{array}$ & 3,4 & 2 \\
\hline & & $\begin{array}{l}\text { Memahami } \\
\text { kemampuan peserta } \\
\text { didik }\end{array}$ & $5,6,7,8$ & 4 \\
\hline & $\begin{array}{l}\text { Mempunyai } \\
\text { pengetahuan dan } \\
\text { menguasai bidang } \\
\text { studi } \\
\text { dibinanya }\end{array}$ & $\begin{array}{l}\text { Kemampuan } \\
\text { menyusun perangkat } \\
\text { penilaian hasil } \\
\text { belajar dalam proses } \\
\text { pembelajaran }\end{array}$ & 9,10 & 2 \\
\hline & & $\begin{array}{l}\text { Penguasaan terhadap } \\
\text { landasan } \\
\text { kependidikan }\end{array}$ & 11,12 & 2 \\
\hline & $\begin{array}{lr}\text { Mempunyai sikap } \\
\text { yang tepat tentang } \\
\text { dirinya sendiri, } \\
\text { sekolah, teman } \\
\text { sejawat, dan bidang } \\
\text { studi yang } \\
\text { dibinanya }\end{array}$ & $\begin{array}{l}\text { Rasa bangga dan } \\
\text { percayadiri }\end{array}$ & 13,14 & 2 \\
\hline & & $\begin{array}{lr}\text { Menampilkan diri } \\
\text { sebagai pribadi yang } \\
\text { jujur, teladan, } \\
\text { berwibawa } \\
\text { bijaksana }\end{array}$ & $\begin{array}{r}15,16,17,1 \\
8,19\end{array}$ & 3 \\
\hline & & $\begin{array}{l}\text { Tanggungjawab } \\
\text { dalam bekerja }\end{array}$ & $20,21,22$ & 3 \\
\hline & & $\begin{array}{l}\text { Berkomunikasi } \\
\text { secara efektif dengan } \\
\text { peserta didik, } \\
\text { pendidik dan tenaga }\end{array}$ & $23,24,25$ & 3 \\
\hline
\end{tabular}




$\begin{array}{llrr} & \text { kependidikan } & & \\ & \begin{array}{l}\text { Menguasai } \\ \text { yang dibina }\end{array} & 26 & 1 \\ & \text { Mengelola } & 27,28,29, & 4 \\ \begin{array}{l}\text { Mempunyai } \\ \text { keterampilan untuk } \\ \text { mengajar }\end{array} & \text { pembelajaran } & 30 & \end{array}$

Pada tabel 1, Dalam penelitian ini, peneliti menggunakan skala likert untuk menghitung skor instrumen. Skala likert digunakan untuk mengukur sikap, pendapat, dan persepsi seseorang atau sekelompok orang tentang fenomena sosial. Dengan skala likert, maka variabel yang akan diukur dan dijadikan menjadi indikator tersebut dijadikan titik tolak untuk menyususn item-item instrumen yang dapat berupa pernyataan atau pertanyaan (Sugiyono, 2017). Penelitian ini menggunakan kuesioner pernyataan. Jawaban responden berupa pilihan dari 5 alternatif yang ada di tabel 2 .

Tabel 2 Kriteria penilaian alternatif jawaban skala likert

\begin{tabular}{llr}
\hline No & \multicolumn{1}{c}{ Variabel Y } & Nilai \\
\hline 1 & SL (Selalu) & 5 \\
2 & SR (Sering) & 4 \\
3 & KK (Kadang-Kadang) & 3 \\
4 & P (Pernah) & 2 \\
5 & TP (Tidak Pernah) & 1 \\
\hline
\end{tabular}

\section{Teknik Analisis Data}

\section{Uji Prasyarat Analisis}

Uji prasyarat analisis bertujuan untuk menguji apakah data yang terkumpul memenuhi persyaratan untuk dianalisa atau tidak. Adapun ujian prasyarat analisis meliputi uji normalitas dan uji linearitas (Muharto,2012). Uji normalitas dilakukan untuk mengetahui normal atau tidaknya suatu distribusi data (Supardi, 2013 ). Dalam penelitian ini menggunkan uji Kolmogorov/Smirnov dengan bantuan SPSS versi 2.1 untuk menghitung normalitas data variabel Y yaitu prosionalitas guru. Uji linearitas digunakan untuk melihat garis regresi antara $\mathrm{X}$ (STIFIn) dan $\mathrm{Y}$ (Profesionaltas Guru) membentuk garis linear atau tidak. Pengujian linearitas dilakukan menggunakan bantuan program SPSS versi 2.1 dua variabel dikatakan mempunyai hubungan linear apabila nilai signifikansinya kurang dari 0,05.

Analisis data yang telah dikumpulkan kemudian dilakukan analisis chi square/ kaikuadrat untuk menguji hubungan antara variabel bebas terhadap variabel terikat. Adapun langkah analisis sebagai berikut:

1. Menghitung rata-rata skor responden, untuk menghitung kecenderungan jawaban responden terhadap variabel penelitian menggunakan rumus Weight Mean Score (WMS)

2. Analisis Korelasi

a. Uji Chi Square/ Kai Kuadrat

Untuk menguji hipotesis, peneliti akan menggunakan teknik analisis Chi-Square/ Kai Kuadrat (X) dipergunakan untuk menguji data dalam bentuk kelompok dalam tabel distribusi frekuensi. (Supardi, 2013). 


\section{HASIL DAN PEMBAHASAN}

\section{Hasil}

\section{STIFIn}

Penelitian ini mendeskripsikan hubungan antara dua variabel (X) STIFIn dengan (Y) Profesionalitas guru. Deskripsi data STIFIn dilihat dari data guru yang sudah melaksanakan tes STIFIn terdapat 23 orang guru adapun datanya dapat dilihat pada tabel 3.

Tabel 3 Hasil tes STIFIn guru

\begin{tabular}{lll}
\hline No & \multicolumn{1}{c}{ Nama } & Personality Genetic \\
\hline 1 & Rusli & sensing introvert \\
2 & Nasution & sensing introvert \\
3 & Restu Ariyani & sensing introvert \\
4 & Adhi Rachmat Saputra & sensing Extrovert \\
5 & Achmad Kabir Rifa'i & sensing Extrovert \\
6 & Saeful Mujib Al-Rahman & sensing Extrovert \\
7 & LitaLidya & sensing Extrovert \\
8 & Rinda Aeniah & sensing Extrovert \\
9 & Eva Hariani Dalimunthe & Thinking Introvert \\
10 & Dedi Kiswanto & Thinking Introvert \\
11 & Sujaji & Thinking Introvert \\
12 & Dina Rosdiana & Thinking Introvert \\
13 & Lu'lu Ilmaknun & Thinking Introvert \\
14 & Shildi Andriani & Intuiting Introvert \\
15 & Dede Jamaludin & Intuiting Introvert \\
16 & Oktavia Aini Zakaria & Intuiting Introvert \\
17 & Nanang Syarifudin & Intuiting Introvert \\
18 & Mohammad Taufiq Aziz & Feeling extrovert \\
19 & Panca Pribadi & Feeling extrovert \\
20 & Eva Rudianti & Feeling Introvert \\
21 & Yukie Saraswati Aprilia & Feeling Introvert \\
22 & Siti Nur Arsyillah Al'aliyah & Insting \\
23 & Novan Abdul Humaemi & Insting \\
\hline & &
\end{tabular}

\section{Profesionalitas Guru}

Pada tahap analisis data untuk mengetahui profesionalitas guru, secara statistik dilakukan perhitungan kecenderungan atau rerata data penelitian pada masing-masing variabel. Mengukur kecenderungan skor responden dari masing-masing variabel. Mengukur kecenderungan skor responden dilakukan dengan menggunakan Weight Mean Score (WMS) yang kemudian ditafsirkan melalui kriteria penafsiran, sesuai dengan tabel 4.

Tabel 4 Kriteria penafsiran

\begin{tabular}{ll}
\hline \multicolumn{1}{c}{ Interval Score } & \multicolumn{1}{c}{ Kriteria } \\
\hline $4,6-5,4$ & Sangat Baik \\
$3,7-4,5$ & Baik \\
$2,8-3,6$ & Cukup Baik \\
$1,9-2,7$ & Tidak Baik \\
$1-1,8$ & Sangat Tidak Baik \\
\hline
\end{tabular}

Pada tabel 4 kriteria penafsiran Gambaran serta hasil perhitungan WMS, kecenderungan skor rata-rata setiap indikator variabel profesionalitas guru dapat dilihat pada tabel 5 .

Tabel 5 Hasil perhitungan WMS rata-rata indikator variabel $\mathrm{Y}$ profesionalitas guru

\begin{tabular}{|c|c|c|c|}
\hline No & Indikator & $\begin{array}{l}\text { Rata- } \\
\text { Rata }\end{array}$ & Kategori \\
\hline 1 & $\begin{array}{l}\text { mempunyai } \\
\text { pengetahuan } \\
\text { tentang belajar } \\
\text { dan tingkah laku } \\
\text { manusia }\end{array}$ & 4,48 & Baik \\
\hline 2 & $\begin{array}{l}\text { mempunyai } \\
\text { pengetahuan dan } \\
\text { menguasai } \\
\text { bidang studi } \\
\text { yang dibinanya }\end{array}$ & 4,64 & $\begin{array}{l}\text { Sangat } \\
\text { Baik }\end{array}$ \\
\hline 3 & $\begin{array}{l}\text { mempunyai } \\
\text { sikap yang tepat } \\
\text { tentang dirinya } \\
\text { sendiri, sekolah, } \\
\text { teman sejawat }\end{array}$ & 4,74 & $\begin{array}{l}\text { Sangat } \\
\text { Baik }\end{array}$ \\
\hline
\end{tabular}




\begin{tabular}{lrl}
\hline \multicolumn{3}{c}{ dan bidang studi } \\
yang dibinannya \\
$4 \quad \begin{array}{l}\text { mempunyai } \\
\text { keterampilam } \\
\text { untuk mengajar }\end{array}$ & 4,63 Sangat \\
Baik \\
$\begin{array}{l}\text { Total Rata-Rata } \\
\text { keseluruhan }\end{array}$ & 4,62 & $\begin{array}{l}\text { Sangat } \\
\text { Baik }\end{array}$ \\
\hline
\end{tabular}

Berdasarkan pengolahan data hasil perhitungan WMS pada tabel 5 di atas menunjukkan bahwa rata-rata keseluruhan data sangat baik yaitu 4,62.

\section{Uji Prasyarat Analisis}

Peneliti menggunakan dua macam uji yaitu uji normalitas dan linearitas.

\section{Uji Normalitas}

Uji normalitas digunakan untuk mengetahui distribusi penyebaran data variabel $Y$ (Profesionalitas Guru) penelitian ini menggunakan Kolmogorov/ Smirnov. Perhitungannya menggunakan program SPSS versi 2.1. adapun hasilnya dapat dilihat pada tabel 6 .

Tabel 7 Hasil uji linearitas
Tabel 6 Hasil uji normalitas

\begin{tabular}{llr}
\hline \multicolumn{2}{c}{ One-Sample Kolmogorov-Smirnov Test } \\
\hline & & $\begin{array}{r}\text { Profesionalitas } \\
\text { Guru }\end{array}$ \\
\hline $\mathrm{N}$ & Mean & 23 \\
Normal & Std. & 130.2174 \\
Parameters ${ }^{\mathrm{a}, \mathrm{b}}$ & Deviation & \\
& Absolute & .190 \\
Most Extreme & Positive & .130 \\
Differences & Negative & $-.190-$ \\
Kolmogorov-Smirnov Z & .912 \\
Asymp. Sig. (2-tailed) & .377 \\
\hline
\end{tabular}

Dari hasil perhitungan uji normalitas pada tabel 6 diperoleh data profesionalitas dengan Sig $(2$-tailed $=0,240)>$ sehingga berdistribusi normal.

\section{Uji Linearitas}

Uji linearitas pada prinsipnya untuk mengetahui antara variabel bebas (X) dan variabel terikat (Y) linear atau tidak.

\begin{tabular}{|c|c|c|c|c|c|c|c|}
\hline \multicolumn{8}{|c|}{ ANOVA Table } \\
\hline & & & $\begin{array}{l}\text { Sum of } \\
\text { Squares }\end{array}$ & $\mathrm{df}$ & $\begin{array}{l}\text { Mean } \\
\text { Square }\end{array}$ & $\mathrm{F}$ & Sig. \\
\hline \multirow{6}{*}{$\begin{array}{l}\text { STIFIn * } \\
\text { Profesionalitas_Guru }\end{array}$} & \multirow{4}{*}{$\begin{array}{l}\text { Between } \\
\text { Groups }\end{array}$} & (Combined) & 61.822 & 13 & 4.756 & 3.592 & .031 \\
\hline & & Linearity & 5.161 & 1 & 5.161 & 3.898 & .080 \\
\hline & & Deviation & 56.661 & 12 & 4.722 & 3.566 & .032 \\
\hline & & Linearity & & & & & \\
\hline & \multicolumn{2}{|c|}{ Within Groups } & 11.917 & 9 & 1.324 & & \\
\hline & \multicolumn{2}{|l|}{ Total } & 73.739 & 22 & & & \\
\hline
\end{tabular}

Berdasarkan hasil analisis tabel 7 diperoleh Sig $(0,0031)>(0,05)$ sehingga Ho diterima. Dengan demikian hubungan STIFIn degan Profesionalitas guru bersifat linier. Pada tahap analisis data, data dari hasil pengolahan kuesioner dianalisis menggunakan pendekatan Weight Mean Score (WMS). Adapun hasil perhitungan data pada masing-masing kecerdasan dapat dilihat pada tabel 8 . 
Tabel 8 Hasil perhitungan rata-rata nilai STIFIn

\begin{tabular}{|c|c|c|c|c|c|}
\hline \multirow{2}{*}{ STIFIn } & \multicolumn{4}{|c|}{ Indikator } & \multirow{2}{*}{ Rata-Rata } \\
\hline & 1 & 2 & 3 & 4 & \\
\hline Sensing Introvert & 4,94 & 4,83 & 4,72 & 4,83 & 4,83 \\
\hline Sensing Extrovert & 4,56 & 4,3 & 4,8 & 4,65 & 4,57 \\
\hline Thinking Introvert & 4,56 & 4,85 & 4,8 & 4,7 & 4,72 \\
\hline Intuiting Introvert & 4,25 & 4,62 & 4,92 & 4,25 & 4,51 \\
\hline Feeling Extrovert & 4,58 & 4,75 & 4,67 & 4,37 & 4,59 \\
\hline Feeling Introvert & 4,41 & 4,62 & 4,75 & 4,37 & 4,53 \\
\hline Insting & 4,16 & 4,75 & 4,75 & 4,5 & 4,54 \\
\hline
\end{tabular}

Pada tabel 8, Sebelum diuraikan tentang kategorisasi hasil kuesioner yang pengolahan dan analisis data hasil penelitian lapangan menggunakan dilaksanakan pada 23 orang guru di SMK kuesioner, maka peneliti terlebih dahulu Informatika PESAT Bogor. Adapun datanya dapat dilihat pada tabel 9 . menyediakan data variabel $\mathrm{X}$ dan Y dengan Tabel 9 Data hasil tes STIFIn guru dan hasil kuesioner profesionalitas guru

\begin{tabular}{|c|c|c|c|c|c|}
\hline \multirow{2}{*}{ No } & \multicolumn{2}{|c|}{ STIFin } & \multicolumn{3}{|c|}{ Profesionalitas Guru } \\
\hline & Data & Kategori & Rata-Rata & Keterangan & Kategori \\
\hline 1 & sensing introvert & 1 & 4,83 & Sangat Baik & 5 \\
\hline 2 & sensing introvert & 1 & 4,83 & Sangat Baik & 5 \\
\hline 3 & sensing introvert & 1 & 4,83 & Sangat Baik & 5 \\
\hline 4 & sensing Extrovert & 2 & 4,57 & Sangat Baik & 5 \\
\hline 5 & sensing Extrovert & 2 & 4,57 & Sangat Baik & 5 \\
\hline 6 & sensing Extrovert & 2 & 4,57 & Sangat Baik & 5 \\
\hline 7 & sensing Extrovert & 2 & 4,57 & Sangat Baik & 5 \\
\hline 8 & sensing Extrovert & 2 & 4,57 & Sangat Baik & 5 \\
\hline 9 & Thinking Introvert & 3 & 4,72 & Sangat Baik & 5 \\
\hline 10 & Thinking Introvert & 3 & 4,72 & Sangat Baik & 5 \\
\hline 11 & Thinking Introvert & 3 & 4,72 & Sangat Baik & 5 \\
\hline 12 & Thinking Introvert & 3 & 4,72 & Sangat Baik & 5 \\
\hline 13 & Thinking Introvert & 3 & 4,72 & Sangat Baik & 5 \\
\hline 14 & Intuiting Introvert & 4 & 4,51 & Baik & 4 \\
\hline 15 & Intuiting Introvert & 4 & 4,51 & Baik & 4 \\
\hline 16 & Intuiting Introvert & 4 & 4,51 & Baik & 4 \\
\hline 17 & Intuiting Introvert & 4 & 4,51 & Baik & 4 \\
\hline 18 & Feeling extrovert & 5 & 4,59 & Baik & 4 \\
\hline
\end{tabular}




\begin{tabular}{|c|c|c|c|c|c|}
\hline 19 & Feeling extrovert & 5 & 4,59 & Baik & 4 \\
\hline 20 & Feeling Introvert & 6 & 4,53 & Baik & 4 \\
\hline 21 & Feeling Introvert & 6 & 4,53 & Baik & 4 \\
\hline 22 & Insting & 7 & 4,54 & Baik & 4 \\
\hline 23 & Insting & 7 & 4,54 & Baik & 4 \\
\hline
\end{tabular}

Pada tahapan ini dimaksudkan untuk menganalisis data secara statistik tentang korelasi variabel X dan Y. Berdasarkan data pada tabel 9 dengan membuat rumus chi kuadrat, tabel kontingensi setelah itu disajikan dan diberi kesimpulan. Pada penelitian ini terdapat 2 variabel yaitu STIFIn dan Profesionalitas Guru yang memiliki empt kategori. Dengan demikian pengujian dengan chi-kuadrat penelitian mempunyai $7 \times 2$. Tabel kontingensinya dapat dilihat pada tabel 10 .

Tabel 10 Tabel kontingensi antara STIFIn dengan profesionalitas guru

Count

\begin{tabular}{|c|c|c|c|}
\hline & \multicolumn{2}{|c|}{$\begin{array}{c}\text { Profesionalitas } \\
\text { Guru }\end{array}$} & \multirow[t]{2}{*}{ Total } \\
\hline & Baik & $\begin{array}{c}\text { Sangat } \\
\text { Baik }\end{array}$ & \\
\hline $\begin{array}{l}\text { sensing } \\
\text { introvert }\end{array}$ & 0 & 3 & 3 \\
\hline $\begin{array}{l}\text { sensing } \\
\text { extrovert }\end{array}$ & 0 & 5 & 5 \\
\hline $\begin{array}{l}\text { Thinking } \\
\text { Introvert }\end{array}$ & 0 & 5 & 5 \\
\hline $\begin{array}{r}\text { STIFInIntuiting } \\
\text { Introvert }\end{array}$ & 4 & 0 & 4 \\
\hline $\begin{array}{l}\text { Feeling } \\
\text { Extrovert }\end{array}$ & 2 & 0 & 2 \\
\hline $\begin{array}{l}\text { Feeling } \\
\text { Introvert }\end{array}$ & 2 & 0 & 2 \\
\hline Insting & 2 & 0 & 2 \\
\hline Total & 10 & 13 & 23 \\
\hline
\end{tabular}

\section{Perhitungan}

Setelah jumlah pada baris dan jumlah semua diketahui, maka langkah selanjutnya mencari harga chi-kuadrat melalui perhitungan menggunakan SPSS versi 2.1

Tabel 11 Hasil perhitungan chi kuadrat antara X-Y

Chi-Square Tests

\begin{tabular}{lrrr}
\hline & Value & df & $\begin{array}{r}\text { Asymp. Sig. } \\
\text { (2-sided })\end{array}$ \\
\hline Pearson Chi- & $23.000^{a}$ & 6 & .001
\end{tabular}

Square

Likelihood

31.492

6

.000

Ratio

Linear-by-

15.647

1

.000

Linear

Association

$\mathrm{N}$ of Valid23

Cases

a. 14 cells $(100.0 \%)$ have expected count less than 5 . The minimum expected count is 87 .

Berdasarkan hasil pengujian pada tabel 11 menggunakan Chi-kuadrat dengan taraf signifikansi $5 \%$, d.b = 6. Dengan kriteria pengujian, jika <, maka Ho diterima, dan jika >, maka Ho ditolak. Hasil perhitungan dalam tabel diperoleh nilai $=0,01$ dan d.b $=$ 6 didapat nilai $=12,592$, jadi dari hasil tersebut karena nilai $<=0,01<12,592$, maka Ho diterima dan $\mathrm{H}_{1}$ ditolak.

\section{Pembahasan}

Perolehan hasil data perhitungan kuesioner profesionalitas yang dihitung menggunakan rumus Weight Mean Score (WMS) 
menunjukkan bahwa profesionalitas guru di SMK Informatika Pesat Bogor berada pada kategori sangat baik yang memiliki rata-rata 4,62 .

Hasil penelitian menunjukkan bahwa ada hubungan antara variabel X (STIFIn) dengan variabel Y (profesionalitas guru) di SMK Informatika Pesat Bogor. Untuk mengetahui ada apa tidaknya hubungan variabel $\mathrm{X}$ (STIFIn) dengan variabel Y (profesionalitas guru), maka dilakukan pengujian hipotesis menggunakan uji Chi-Square/ Kai Kuadrat. Sebelum dilakukan pengujian hipotesis maka dilakukan uji prasyarat analisis terlebih dahulu yaitu menggunakan uji normalitas Kolmogorov-Smirnov dan uji linearitas. Berdasarkan uji normalitas dan linearitas dapat diketahui bahwa penelitian ini berdistribusi normal dan bersifat linear.

Setelah itu mencari rerata nilai pada masing-masing kuesioner profesionalitas guru (Y) yang disesuaikan dengan masingmasing kecerdasan yang terdapat pada STIFIn, data tersebut diperoleh dan disesuaikan dari data yang sudah ada dari sekolah. Hasil dari rerata nilai tersebut yaitu dijadikan untuk perhitungan selanjutnya yang dikategorikan sesuai dengan kriteria yang sudah ditentukan. Setelah mendapatkan hasil pengkategorian STIFIn (X) dan Profesionalitas Guru (Y).

Hasil penelitian mengenai hubungan antara STIFIn dengan profesionalitas guru menghasilkan bahwa terdapat hubungan antara STIFIn dengan profesionalitas guru. Dimana kesimpulan ini berdasarkan atas d.b =6, melihat pada tabel chi-kuadrat, ternyata harga chi-kuadrat teoritik untuk taraf signifikansi $5 \%=0,05$, untukd.b $=$ 6tarafsignifikansi $5 \%=12,592$. Dengan kriteria pengujian, jika nilai Asymp sig < 0,05 , maka terdapat hubungan yang signifikansi antara baris dengan kolom, dan jika Asymp sig > 0.05, maka tidak terdapat hubungan yang signifikansi antara baris dengan kolom. Hasil dari perhitungan uji chi square yaitu Asymp sig =0,01, nilai Asymp sig $0.01<0.05$, atau 0,01<12,592, dengan demikian dapat disimpulkan terdapat hubungan yang signifikan antara baris dengan kolom. Berarti terdapat hubungan antara STIFIn (X) dengan profesionalitas guru (Y) tetapi hubungannya sangat lemah.

\section{KESIMPULAN DAN IMPLIKASI}

\section{Kesimpulan}

Berdasarkan hasil penelitian mengenai "Hubungan STIFIn dengan Profesionalitas Guru, maka dapat disimpulkan bahwa terdapat hubungan antara STIFIn dengan Profesionalitas Guru di SMK Informatika Pesat Bogor, tetapi sangat lemah. Berdasarkan uji dari hasil penelitian melihat pada tabel chi-kuadrat, atas d.b $=6$, harga chi-kuadrat teoritik untuk taraf signifikansi $5 \%=0.05$, untuk d.b $=6$ signifikansi $5 \%=$ 12,592. Dengan kriteria pengujian nilai Asymp sig < 0.05, maka terdapat hubungan yang signifikan antara baris dengan kolom. Hasil perhitungan dalam tabel chi-kuadrat yaitu Asymp sig 0,01, nilai Asymp sig 0,01 < 0.05 , atau $0.01<12.592$, dengan demikian dapat disimpulkan terdapat hubungan yang signifikan antara baris dengan kolom.

\section{Implikasi}

Penelitian ini memiliki dampak yang sangat signifikan dalam memudahkan guru untuk mengetahui karakter pribadi masing-masing guru. Serta apakah ada hubungannya antara STIFIn dengan profesionalitas guru tersebut. Memudahkan guru untuk mengevaluasi pembelajaran khususnya dalam mengajar, karena guru tersebut sudah mengetahui kemampuan dirinya sendiri. Dapat meningkatkan mutu sekolah. 
Sekolah dapat menggunakan hasil penelitian ini sebagai promosi untuk sekolah tersebut.

\section{DAFTAR PUSTAKA}

Aqib, Z. (2009). Menjadi Guru Profesional Berstandar Nasional. Bandung: Yrama Widya.

Arikunto, S. (2013). Prosedur Penelitian Suatu Pendekatan Praktek. Jakarta: Rineka Cipta.

Bisri, H. (2012). Kapita Selekta Pendidikan. Bandung: Pustak Setia.

Iskandar. (n.d.). Psikologi Pendidikan Sebuah Orientasi Baru. Jakarta: Referensi.

Muharto. (2012). Metode Penelitian Sistem Informasi. Yogyakarta: Deepublish.
Priansa, D. (2015). Manajemen Peserta Didik Dan Model Pembelajaran . Bandung: Alfabeta.

S.M.Masykur. (2012). Menajamkan Otak dengan shalat. jakarta : Suka Buku.

S.U.Supardi. (2013). Aplikasi Statistika Dalam Penelitian Konsep Statistika Yang Lebih Komprehensip. Jakarta: Change Publication.

Sugiyono. (2017). Metode Penelitian Pendidikan Pendekatan Kuantitatif, Kualitatif, dan R\&D. Bandung: Alfabeta.

Wahab, R. (2016). Psikologi Belajar. Depok: Raja Grafindo Persada. 